Relations industrielles

Industrial Relations

\title{
Our Readers' Comments
}

Volume 4, numéro 5, janvier 1949

URI : https://id.erudit.org/iderudit/1023473ar

DOI : https://doi.org/10.7202/1023473ar

Aller au sommaire du numéro

Éditeur(s)

Département des relations industrielles de l’Université Laval

ISSN

0034-379X (imprimé)

1703-8138 (numérique)

Découvrir la revue

Citer ce document

(1949). Our Readers' Comments. Relations industrielles / Industrial Relations,

4(5), 50-50. https://doi.org/10.7202/1023473ar

Tous droits réservés (C) Département des relations industrielles de l’Université Laval, 1949
Ce document est protégé par la loi sur le droit d'auteur. L’utilisation des services d'Érudit (y compris la reproduction) est assujettie à sa politique d'utilisation que vous pouvez consulter en ligne.

https://apropos.erudit.org/fr/usagers/politique-dutilisation/ 
TABLE 6: VOLUNTARY AND IRREVOCABLE CHECK-OFF PROVISIONS EXISTING EITHER ALONE OR SIMULTANEOUSLY WITH UNION AFFILIATION PROVISIONS IN COLLECTIVE AGREEMENTS COVERING 1823 ESTABLISHMENTS IN THE PROVINCE OF QUEBEC

\begin{tabular}{|c|c|c|c|c|c|c|c|}
\hline & \multirow{2}{*}{ TOTAL } & \multirow{2}{*}{ alone } & \multirow{2}{*}{$\begin{array}{l}\text { closed } \\
\text { shop }\end{array}$} & \multicolumn{2}{|c|}{ Union shop } & \multirow{2}{*}{$\begin{array}{l}\text { preferential } \\
\text { shop }\end{array}$} & \multirow{2}{*}{$\begin{array}{c}\text { maintenance of } \\
\text { membership }\end{array}$} \\
\hline & & & & perfect & imperfect & & \\
\hline $\begin{array}{l}\text { CCCL } \\
\text { TLC } \\
\text { CCL } \\
\text { Ind. Fied. } \\
\text { Others } \\
\end{array}$ & $\begin{array}{r}404 \\
84 \\
27 \\
6 \\
7 \\
\end{array}$ & $\begin{array}{r}40 \\
47 \\
20 \\
4 \\
6 \\
\end{array}$ & $\begin{array}{l}8 \\
2 \\
\\
-\end{array}$ & $\begin{array}{r}19 \\
6 \\
3 \\
2 \\
\end{array}$ & $\begin{array}{r}63 \\
2 \\
- \\
\end{array}$ & $\begin{array}{l}6 \\
1 \\
1 \\
\\
\end{array}$ & $\begin{array}{r}268 \\
26 \\
3 \\
1\end{array}$ \\
\hline TOTALS: & 528 & 298 & 10 & 30 & 65 & 8 & 298 \\
\hline
\end{tabular}

\section{OUR READERS' COMMENTS}

We are always pleased to receive our readers comments and the following are excerpts from their interesting letters :

The general superintendent of a large Canadian Firm employing thousands of workers writes on November 19th, 1948: "I have had an opportunity of seeing your Bulletin on recent occasions and must compliment you on its setup and contents. I am particularly interested in the effort to recognize the features which distinguish a Christian Social Order and the steps which might be taken to promote it. I should, therefore, like to obtain a copy of the bulletin "Structural Reforms In Enterprise" when it is available. I should also be glad of any other suggestions which you would care to make as to reference material."

Mr. L.-O. Morency, General Manager, Brique Citadelle Ltée, Québec, who has about one hundred employees, makes the following representations in his letter of December 14th, 1948: "Je reçois votre Bulletin des relations industrielles", Vol. 4, No 3. novembre. Une fois de plus, je constate que cette publication en est une unilatérale, soit ouvrière et alors pourquoi ne pas en changer le titre et l'appeler "Bulletin de la Classe Ouvrière". J'ai déjà eu l'occasion de vous dire que l'ouvrier reçoit toute ma sympathie de même que celle de ma Compagnie, et je crois que dans le domaine des améliorations, ils ont été généreusement traités. Comme vous le savez fort bien, toute médaille a deux côtés, et il faut se demander où nous mènera cette publicité toujours en leur faveur sans même les mettre en garde sur l'exagération de leurs exigences car il peut très bien arriver que l'on parvienne à tuer la poule aux oeufs d'or, et il nous restera qu'à s'en repentir. Il serait très agréable de lire un article où l'on signalerait que plusieurs industriels ont à peu près atteint le sommet des salaires et prix de leur produits sans risquer de contribuer à une inflation, laquelle ne serait pas j'imagine recommandable pour Québec, la Province et tout le Pays."

Mr. W.C. Budgeon, Personnel Manager, Brown Corporation, La Tuque, makes the following statement in his letter of January 6th, 1949: "I am writting you to tell you how much we are appreciating your Bulletin des Relations Industrielles. I feel that there has been a definite improvement during the last twelve months, both in the contents and form of your bulletin. I have found it most informative and interesting. I feel that its value is greatly. increased by the fact that it is now bilingual. Too often, our appreciation of a periodical such as yours is not expressed and that is the reason that I am taking this opportunity to write you personally and tell you how much we here appreciate it."

When you stop to ask yourself where our company is heading as regards labour relations, may I leave the thought with you that you, management, have made history by stupendous feats of engineering, chemistry, metallurgy and mass production. You of management must arrange for capital to replace worn out machines (but I am afraid that most of us for many, many years, have overlooked the fact that it is just as important to do something about worn out human machines as it is to arrange for replacing worn out equipment), if we are to have the final answer in bringing capital and labour together.

\author{
F. A. Serman
}

(Industrial Canada)

President, Dominion Foundries of Steel, Limited, Hamilton, Ont. 